\title{
STUDI DOKUMENTER HASIL BELAJAR PSIKOMOTOR MATERI KLASIFIKASI MAKHLUK HIDUP DENGAN MENGGUNAKAN MODEL PJBL PADA SISWA KELAS VII MTSN 11 CIAMIS
}

\author{
Teni Setia Mulyani ${ }^{1)}$, Euis Erlin ${ }^{2)}$, Lia Yulisma ${ }^{2)}$ \\ 1) Guru SD 1 Sindanglaya kecamatam Sukamantri, Kabupaten Ciamis \\ 2) Staf Pengajar Program Studi Pendidikan Biologi FKIP Universitas Galuh, Ciamis \\ Email: mulyaniteni3@gmail.com
}

\begin{abstract}
The purpose of the documentary reasearch to study the effectiveness of PjBL teaching model and the factors that can influence the effectiveness of the PjBL model on the psychomotor learning outcomes in the material classification of living things. The subject of the study was the document of the psychomotor learning outcomes of Grade VII students in MTsN 11 Ciamis The Simple random sampling was taken. This research is a qualitative study through a triangulation approach. The instruments used in the form of psychomotor learning outcomes documents, interview questionnaires, as well as several other documents that can affect on learning outcomes include lesson plans, teaching materials, and learning media.. Analysis of data through reduction, presenting and analysis. The results showed that psychomotor learning outcomes are in the excellent category. Conclution of the study that achievement of learning outcomes is influenced by various factors both from students and from the learning environment. Factors that can affect the effectiveness of the use of the PjBL model include: (1) discussion groups, (2) feelings of hopelessness, and (3) students' motivation to learn. The implication of this study can be used to improve psychomotor learning outcomes by using the PjBL model on the material classification of living things
\end{abstract}

Keywords: Effectiveness, PjBL and Psychomotor Learning Outcomes.

\section{ABSTRAK}

Tujuan studi dokumenter ini untuk mengetahui keefektifan model PjBL serta faktor-faktor yang dapat mempengaruhi keefektifan model PjBL terhadap hasil belajar psikomotor siswa pada materi klasifikasi makhluk hidup di MTsN 11 Ciamis. Penelitian ini merupakan penelitian secara kualitatif melalui pendekatan triangulasi. Instrumen yang digunakan berupa dokumen hasil belajar psikomotor, kuesioner wawancara, serta beberapa dokumen lain yang dapat mempengaruhi hasil belajar diantaranya RPP, bahan ajar yang digunakan, serta media pembelajaran. Subjek penelitian adalah dokumen hasil belajar psikomotor siswa kelas VII A. Sampel diambil secara acak sederhana (Simple Random Sampling). Teknik analisis data melalui reduksi, menyajikan data, dan analisis data. Hasil penelitian menunjukan bahwa hasil belajar psikomotor berada dalam kategori baik sekali. Kesimpulan penelitian ini bahwa ketercapaian hasil belajar dipengaruhi oleh berbagai faktor baik dari diri siswa maupun dari lingkungan belajar. Faktor yang dapat mempengaruhi keefektifan penggunaan model PjBL diantaranya: (1) kelompok diskusi, (2) rasa tidak mudah putus asa, serta (3) motivasi siswa untuk belajar. Implikasi dari penelitian ini yaitu guru dapat menggunakan model PjBL untuk meningkatkan hasil belajar psikomotor khusunya pada materi klasifikasi makhluk hidup.dan perlu dilakukan penelitian lanjutan untuk materi yang lain.

Kata kunci: Hasil Belajar Psikomotor, Keefektifan, PjBL,

\section{PENDAHULUAN}

Pendidikan merupakan perkara yang penting dalam mencapai kesejahteraan dan kesempurnaan hidup manusia (Mandang, et al: 2017). Pada dunia pendidikan tidak terlepas dari belajar dan pembelajaran. Menurut Emda (2017) belajar adalah perubahan perilaku yang relatif tetap dan melekat pada seseorang serta akan aktif untuk mencari informasi sehingga mendapatkan suatu pengetahuan. Sementara pembelajaran adalah suatu proses berinteraksi antara guru dengan siswa dan sumber belajar dalam lingkungan belajar (Mulyono,2015:43).

IPA adalah salah satu mata pelajaran di Sekolah Menengah Pertama (SMP). Dalam pembelajaran IPA tidak hanya membahas mengenai pengetahuan berupa fakta-fakta, konsepkonsep, atau prinsip-prinsip saja, namun juga merupakan suatu proses penemuan. Sudjino dan Waljinah (2009, dalam Permana et al, 2014:255) IPA merupakan bagian dari ilmu pengetahuan yang masih berkaitan dengan makhluk hidup dan alam semesta, dimana perlu adanya suatu eksperimen untuk penguatan secara konseptual. Dalam hal ini penerapan model pembelajaran PjBL dianggap tepat untuk digunakan. PjBL merupakan pembelajaran berbasis proyek merupakan model pembelajaran yang melibatkan siswa secara langsung saat pembelajaran dengan melakukan kegiatan 
penelitian untuk mengerjakan dan menyelesaikan suatu proyek tertentu (Abidin, 2014:167) .Karaktristik model PjBL dapat memfasilitasi dalam membangun kemampuan psikomotor. Ranah psikomotor merupakan ranah yang berkaitan dengan keterampilan atau kemampuan bertindak setelah menerima pengalaman belajar. Hasil belajar pada ranah psikomotor nampak dalam bentuk keterampilan dan kemampuan bertindak individu.

Beberapa hasil penelitian yang relevan sudah dilakukan. Penerapan model PjBL sesuai dengan penelitian yang telah dilakukan oleh Nadya et al (2015) bahwa pembelajaran PjBL dapat berpengaruh terhadap keterampilan psikomotor siswa. Hal ini didukung oleh penelitian lain yang dilakukan oleh Fauziyyah N dan Mustaji (2018) bahwa penerapan model PjBL mengalami peningkatan hasil belajar pada materi klasifikasi makhluk hidup yang dilakukan terhadap siswa kelas VII di SMP Negeri 2 Taman Sidoarjo.

Penelitian ini dilakukan berdasarkan observasi yang telah dilakukan kepada salah satu guru IPA kelas VII melalui wawancara . Informasi yang diperoleh menjelaskan bahwa dalam pembelajaran sudah menerapkan model Project Based Leraning (PjBL) pada beberapa materi. Pernyataan tersebut yang mendorong peneliti untuk melakukan analisis mengenai keefektifan penggunaan model PjBL dalam pembelajaran IPA pada materi Klasifikasi Makhluk Hidup.

Tujuan dari penelitian ini diantaranya untuk mengetahui: (1) keefektifan penggunaan model PjBL pada pembelajaran klasifikasi makhluk hidup; (2) faktor-faktor yang dapat mempengaruhi keefektifan model PjBL; serta (3) hasil belajar psikomotor siswa pada materi klasifikasi makhluk hidup dengan mengunakan model PjBL. Untuk mencapai tujuan penelitian, metode yang digunakan berupa metode kualitatif melalui pendekatan triangulasi.

Berdasarkan hasil penelitian yang telah dilakukan, dapat disimpulkan bahwa: (1) Penerapan model Project Based Learning efektif digunakan dalam pembelajaran pada materi klasifikasi makhluk hidup di MTsN 11 Ciamis; (2) Keefektikan model Project Based Learning dipengaruhi oleh faktor internal dan eksternal, yaitu: kelompok diskusi, rasa tidak mudah putus asa dalam diri siswa ketika mengalami kegagalan, serta motivasi siswa untuk belajar; serta (3) hasil belajar psikomotor pada materi klasifikasi makhluk hidup mencapai kategori baik sekali, dengan mencapai nilai maksimal yang didapatkan oleh 7 dari 22 siswa.

Hasil penelitian ini memiliki implikasi yang positif bagi berbagai pihak yang bersangkutan. Hal ini dapat dilihat bahwa penerapan model PJBL efektif digunakan pada materi kalsifikasi makhluk hidup. Selain itu, melalui penerapan model PjBL juga berpengaruh terhadap hasil belajar psikomotor siswa. Penerapan model PjBL menuntut siswa untuk membuat proyek berupa herbarium tanaman.

Hal yang diperoleh dari hasil penelitian menunjukan bahwa model PjBL efektif digunakan untuk melatih psikomotor siswa. Keefektifan model tersebut dipengaruhi oleh beberapa faktor diantaranya: (1) kelompok diskusi, (2) rasa tidak mudah putus asa, dan (3) motivasi siswa untuk belajar. Hasil belajar psikomotor siswa memperoleh rata-rata nilai mencapai 89 dengan kategori baik sekali.

\section{METODE PENELITIAN}

Penelitian ini menggunakan metode kualitatif melalui pendekatan triangulasi. Instrumen yang digunakan dokumen hasil belajar psikomotor, kuesioner wawancara, serta beberapa dokumen lain yang dapat mempengaruhi hasil belajar diantaranya RPP, bahan ajar yang digunakan, serta media pembelajaran. Pengumpulan data dilakukan melalui wawancara langsung dengan guru mata pelajaran IPA kelas VII, serta meminta berkas yang bersangkutan dengan pembelajaran yang dilakukan. Teknik analisis data diolah dengan cara reduksi, menyajian data, dan analisis data. Analisis data disajikan dalam bentuk persentase, berdasarkan rubrik penilaian dengan rumus berikut:

Persentase $(\%)=\frac{\mathrm{f}}{\mathrm{N}} \times 100 \%$

Ket:

$\mathrm{f}=$ Jumlah siswa melebihi KKM

$\mathrm{N}$ = Jumlah seluruh siswa 
Dari hasil perhitungan tersebut maka akan dapat melakukan penarikan kesimpulan berdasarkan hasil belajar yang diperoleh. Hasil penelitian menunjukkan bahwa hasil belajar psikomotor mencapai kategori baik sekali dengan nilai rata-rata yang diperoleh yaitu 89 .

\section{HASIL DAN PEMBAHASAN}

Hasil penelitian diperoleh dari pengumpulan disajikan dalam tabel 1 dan 2.

Tabel 1. Hasil Nilai Psikomotor

\begin{tabular}{ccc}
\hline Hasil Belajar & Nilai & Kriteria \\
\hline Rata-Rata & 89 & Baik sekali \\
\hline Nilai Tertinggi & 100 & Baik sekali \\
\hline Nilai Terendah & 67 & Baik \\
\hline
\end{tabular}

Pada tabel diatas, dapat diketahui rata-rata siswa memperoleh nilai 89 dengan kriteria (baik sekali). Pencapaian rata-rata nilai yang diperoleh siswa menunjukan bahwa menerapan model PJBL efektif digunakan pada materi tersebut. Keefektifan model yang diterapkan tidak terlepas dari faktorfaktor yang dapat mempengaruhinya. Hal ini sesuai dengan wawancara yang mengungkapkan bahwa keefektifan penggunaan model PjBL terdiri dari beberapa faktor yaitu: (1) kelompok diskusi, (2) rasa tidak mudah putus asa, serta (3) motivasi siswa untuk belajar.

Ketercapaian hasil belajar psikomotor tidak terlepas dari berbagai faktor baik dalam diri siswa maupun dari lingkungan belajar. Menurut Susanto (2013:15-18 dalam Surya et al, 2018) bahwa terdapat beberapa faktor yang mempengaruhi hasil belajar diantaranya kecerdasan, kesiapan atau kematangan siswa dalam mengikuti kegiatan pembelajaran, minat siswa dalam pembelajaran, model penyajian materi pembelajaran yang diterapkan guru, serta suasana belajar yang menyenangkan.

Pencapaian nilai siswa berhubungan dengan keefektifan model yang diterapkan. Keefektifan model PjBL yang diterapkan dalam materi klasifikasi makhluk hidup dengan pembuatan herbarium sebagai proyeknya.

\begin{tabular}{|c|c|c|}
\hline $\begin{array}{l}\text { Jumlah } \\
\text { Siswa }\end{array}$ & $\begin{array}{c}\text { Persentase } \\
(\%)\end{array}$ & Kriteria \\
\hline 13 & 59,09 & Sangat Efektif \\
\hline 7 & 31,82 & Cukup Efektif \\
\hline 2 & 9,09 & Kurang Efektif \\
\hline
\end{tabular}

Berdasarkan tabel diatas, dapat diketahui bahwa penerapan model PjBL efektif dengan mencapai $59,09 \%$ siswa berada dalam kriteria sangat efektif. Keefektifan tersebut dilihat berdasarkan aspek-aspek penilaian produk herbarium.

Penerapan model PjBL yang efektif dalam pembelajaran tentunya tidak terlepas dari faktorfaktor yang mendukungnya. Hal ini diutarakan oleh Bukhori (2015) bahwa faktor yang mempengaruhi hasil belajar terdiri dari 2 faktor yaitu: (1) faktor internal, faktor yang terdapat dalam diri siswa seperti tidak mudah putus asa serta motivasi untuk belajar, dan (2) faktor eksternal, faktor yang terdapat dari luar diri seperti bahan pelajaran dan situasi lingkungan contoh pengaruh kelompok diskusi terhadap diri siswa.

Penggunaan model PjBL menuntut siswa untuk membuat suatu proyek dalam pembelajaran. Dalam pembuatan proyek tentunya memerlukan kesiapan baik dalam diri sendiri maupun dari lingkungan. Pada materi klasifikasi makhluk hidup, siswa ditugaskan untuk membuat herbarium tumbuhan. Penugasan tersebut tentunya membutuhkan waktu dan energi dalam pembuatannya. Hal tersebut menuntut siswa untuk tidak mudah berputus asa saat mengalami kegagalan dalam pembuatan herbarium tersebut. Rasa tidak mudah putus asa ditunjang oleh motivasi belajar yang tinggi.

Dalam pelaksanaan penerapan model $\mathrm{PjBL}$, siswa bekerja sama dengan siswa lain untuk mengerjakan proyek yang ditugaskan. Kelompok belajar dapat mempengaruhi diri siswa itu sendiri. 
Hal ini menjadi nilai positif ketika siswa yang kurang pandai tertarik oleh siswa yang pandai. Kedudukan tersebut membuat diri siswa menjadi bersemangat dalam pembelajaran.

Penerapan model PjBL memiliki kelebihan dan kekurangan. Kelebihan model PjBL diantaranya: (1) meningkatkan motivasi belajar dan kemampuan memecahkan masalah; (2) membuat siswa lebih aktif; (3) melatih untuk berkolaborasi; (4) meningkatkan keterampilan siswa dalam mengolah sumber; (5) memberikan pengalaman bagi siswa mengenai pembelajaran dan praktik dalam mengorganisasikan proyek; (6) melibatkan peserta didik untuk belajar, kemudian diimplementasikan dengan dunia nyata; (7) membuat suasana belajar menjadi menyenangkan (Kurniasih, 2014:83 dalam Nurfitriyanti, 2016:155).

Selain mempunyai banyak kelebihan, model PjBL jika memiliki kekurangan, diantanya: (1)membutuhkan biaya banyak; (2) peralatan yang digunakan harus disediakan; (3) siswa akan kesulitan jika yang kurang mahir dalam melakukan percobaan dan pengumpulan data; (4) memungkinkan siswa kurang aktif dalam kerja kelompok; serta (5) jika topik setiap kelompok berbeda, ada kemungkinan tidak semua siswa memahami topik secara keseluruhan (Suhana, 2014: 42-43).

\section{KESIMPULAN}

Berdasarkan hasil analisis yang telah dilakukan maka dapat disimpulkan bahwa: 1)Penerapan model Project Based Learning efektif digunakan dalam pembelajaran pada materi klasifikasi makhluk hidup di MTsN 11 Ciamis, 2) keefektifan model Project Based Learning dipengaruhi oleh faktor internal dan eksternal, yaitu: kelompok diskusi, rasa tidak mudah putus asa dalam diri siswa ketika mengalami kegagalan, serta motivasi siswa untuk belajar, serta 3) hasil belajar psikomotor pada materi klasifikasi makhluk hidup mencapai kategori sangat baik.

\section{DAFTAR PUSTAKA}

Abidin, Y. (2014). Desain Sistem Pembelajaran Dalam Konteks kurikulum 2013. Bandung. Refika Aditama.

Bukhori, eva muzaiyidah. (2015). Faktor-faktor yang Mempengaruhi Hasil Belajar. [Online]. Tersedia: http://evimuzaiyidah.blogspot.com/2015/03/faktor-faktor-yang-mempengaruhibelajar.html?m=1. [14 April 2020].

Emda, amna. 2017. "Kedudukan Motivasi Belajar Siswa dalam Pembelajaran". J. Lantanida. 5(2): 172196

Fauziyyah N dan Mustaji. 2018. "Pengaruh Model Project Based Learning Terhadap Hasil Belajar Mata Pelajaran IPA Materi Pokok Klasifikasi Mahkluk Hidup Pada Kelas VII di SMP Negeri 2 Taman Sidoarjo". J. Mahasiswa Teknologi Pendidikan. 9 (2)

Mandang E F, Lumanau B, Walangitan M D B. (2017). "Pengaruh Tingkat Pendidikan dan Pelatihan Terhadap Kinerja Karyawan pada PT. Bank Rakyat Indonesia (Persero), Tbk Cabang Manado". J. EMBA. 5(3): 4324-4335

Mulyono, nono. (2015). Kurikulum dan Pembelajaran. Ciamis. Riqzi Press

Nadya, Junaidi, dan Warneri. 2015. "Pengaruh Pembelajaran Project Based Learning Terhadap Keterampilan Psikomotorik dan Hasil Belajar Praktek Proyek Work". 1-10

Nurfitriyanti, Maya. 2016. "Model Pembelajaran Project Based Learning Terhadap Kemampuan Pemecahan Masalah Matematika". J. Formatif. 6(2):149-160

Suhana, C. (2014). Konsep Strategi Pembelajaran (ed). Bandung. Refika Aditama.

Surya A P, Relmasira S C, dan Hardini A T. (2018). "Penerapan Model Pembelajaran Project Based Learning (PjBL) Untuk Meningkatkan Hasil Belajar dan Kreativitas Siswa Kelas III SDN Sidorejo Lor 01 Salatiga". J. Pesona Dasar. 6(1):41-54

Permana M S, Johar D, dan Bunyamin. (2014). "Pengembangan Media Pembelajaran Interaktif IImu Pengetahuan Alam (IPA) Berbasis Multimedia”. J. Algoritma. 11(2): 254-263 